\title{
Survey on the Occurrence of Abiotic Diseases on Kiwifruit in Korea
}

\author{
Young Jin Koh ${ }^{1 *}$, Myoung Taek Lim${ }^{1}$, In Ho Jeong ${ }^{1}$, Gyoung Hee Kim ${ }^{1}$, Tae Woong Han ${ }^{1}$, Ju Hoon Cha' and \\ Jong Sup Shin ${ }^{2}$ \\ ${ }^{I}$ Department of Plant Medicine, Sunchon National University, Suncheon 540-742, Korea \\ ${ }^{2}$ Suncheon-Si Agricultural Technology and Extension Center, Suncheon 540-804, Korea
}

(Received on October 11, 2007; Accepted on November 13, 2007)

\begin{abstract}
A survey of the occurrence of abiotic diseases on kiwifruit (Actinidia deliciosa) trees was conducted at sixty-two kiwifruit orchards in twenty-one locations of Jeonnam and Jeju Provinces in Korea during the 2007 growing season. Various kinds of abiotic diseases were detected on the kiwifruit trees. Malformed fruits caused by incomplete pollination were commonly observed among the normally growing fruits on almost all of the kiwifruit trees examined. Fruits imbued with wire rust, fruits scratched or girdled by the wire and fruits injured by sunscald occurred in all of the examined orchards. Abnormal growth of girdled branches by the fence wire, dead trees killed by excessive soil moisture due to poor draining and leaf chlorosis by nutrient deficiencies were found in some orchards. Leaf spotting by herbicide and leaf scorch or blight by excessively high temperature were observed. Leaf blight on young shoots by late frost and bark split on trunks by freeze occurred in several open-field orchards. Flooding and strong wind damages by attack of typhoon 'Nari' were also found during the survey period. Cup-shaped leaves frequently occurred on young shoots in early spring and the incidence of the syndrome tends to increase annually in recent years, which are not etiologically defined until now.
\end{abstract}

\section{Keywords : Abiotic disease, Actinidia deliciosa, Kiwifruit}

Plants grow well within certain ranges of the various factors that make up their environments. Such factors include temperature, soil moisture, soil nutrients, light, wind, air and soil pollutants, air humidity, soil structure, and $\mathrm{pH}$. Although these factors affect all plants growing in nature, importance of some factors is considerably greater for the cultivated plants that are grown in artificial environments such as greenhouses (Katterman, 1990). A number of cultural practices such as pollination, irrigation, draining, pesticide spraying, etc. also affect the growth of the cultivated plants. The common characteristic of abiotic diseases of plants is that they are caused by either a lack or an excess

*Corresponding author.

Phone) +82-61-750-3865, FAX) +82-61-750-3208

E-mail) youngjin@sunchon.ac.kr of something that supports life. Abiotic diseases occur in the absence of pathogens, and cannot, therefore, be transmitted from diseased to healthy plants. The symptoms caused by abiotic diseases vary in kind of and severity with the particular environmental factor. Symptoms may range from slight to severe, and affected plants may even die (Agrios, 2005). Therefore, abiotic diseases may cause considerable damages to plants, leading to significant economic losses.

Diagnosis of an abiotic disease is often as difficult as the diagnosis of a biotic disease. When combinations of single or multiple abiotic and biotic diseases occur on the same plant, however, the disease diagnosis and the determination of the relative importance of each disease become extremely difficult and often impossible. Abiotic diseases can be controlled by ensuring that plants are not exposed to the extreme environmental conditions responsible for such diseases or by supplying the plants with protection or substances that would bring these conditions to levels favorable for plant growth (Agrios, 2005; Bennett, 1993; Katterman, 1990).

Kiwifruit [Chinese gooseberry, Actinidia deliciosa (A. Chev.) C. F. Liang et A. R. Ferguson], which is one of the subtropical fruit trees, has been commercially grown in warm southern regions of Korea since the early 1980s. Kiwifruit is currently cultivated on about 1,500 ha in Korea and large quantities are imported from foreign countries due to increasing demand (Koh, 1995). Several biotic diseases have been reported on kiwifruit (The Korean Society of Plant Pathology, 2004) and some of the biotic diseases have been extensively studied for their effective control (Koh et al., 1996, 1999, 2001, 2003, 2005; Lee et al., 2001, 2005). However, little information is available about abiotic diseases of kiwifruit in Korea. Recently, Bang et al. (2006) investigated some physio- logical disorders of kiwifruit. In this study, A survey was done to investigate the occurrence of abiotic diseases on kiwifruit trees during the 2007 growing season in major kiwifruit cultivation areas of Jeonnam and Jeju Provinces, Korea and the results were reported here. 
Table 1. Survey sites for abiotic diseases in Jeonnam and Jeju Provinces, Korea in 2007

\begin{tabular}{|c|c|c|c|c|}
\hline \multicolumn{3}{|c|}{ Locations } & \multirow{2}{*}{$\begin{array}{l}\text { No. orchards } \\
\text { surveyed }\end{array}$} & \multirow{2}{*}{ Month surveyed } \\
\hline Province & City/Gun & Eup/Myeon/Dong & & \\
\hline \multirow[t]{14}{*}{ Jeonnam } & Suncheon & Haeryong & 5 & Monthly from March to October \\
\hline & & Seo & 5 & Monthly from March to October \\
\hline & Goheung & Doyang & 5 & Monthly from March to October \\
\hline & & Dodeok & 7 & Monthly from March to June \\
\hline & & Donggang & 3 & April, September \\
\hline & & Duwon & 3 & April \\
\hline & & Gwayeok & 2 & April \\
\hline & & Jeomam & 3 & April \\
\hline & & Podu & 1 & April \\
\hline & Boseong & Beolgyo & 1 & July \\
\hline & & Joseong & 4 & May, June, August \\
\hline & Gangjin & Gangjin & 3 & April \\
\hline & Haenam & Okcheon & 2 & April \\
\hline & Wando & Wando & 3 & April \\
\hline \multirow[t]{7}{*}{ Jeju } & Jeju & Aewol & 2 & April \\
\hline & & Samyang & 2 & April \\
\hline & & Jocheon & 3 & April, August \\
\hline & Seogwipo & Seongsan & 4 & April, August \\
\hline & & Dosun & 2 & April \\
\hline & & Topyeong & 1 & April \\
\hline & & Namweon & 1 & August \\
\hline Total & & & 62 & \\
\hline
\end{tabular}

Field survey. Sixty-two kiwifruit orchards, including 40 rain-proof and 22 open-field orchards, from 21 locations of Jeonnam and Jeju Provinces, Korea were surveyed from March to October, 2007 (Table 1). For investigation of disease incidence, we randomly selected more than fifty kiwifruits trees from each orchard.

Abiotic diseases of kiwifruits caused by improper agri-
cultural practices. Artificial pollination for increasing
fertilization frequency is one of the necessary agricultural
practices in kiwifruit orchards because kiwifruit is
dioecious (Warrington \& Weston, 1990). Various kinds of
malformed fruits, which were probably caused by incom-
plete pollination, were commonly observed among the
normally growing fruits on all of the kiwifruit trees ex-
amined. They include small fruits, wide fruits, twin fruits
and malformed fruits with a stripe and small process on
their surfaces (Fig. 1A-D). Such syndromes were similar to
the previously reported defects caused by incomplete polli-
nation (Danbara, 1988). A low incidence of malformed
fruits (approximately 1\% in each orchard) could be attri-
buted to the possibility that malformed fruits might have
been continuously discarded by thinning out during the
growing season by the growers (Table 2).
Fence wire is a basic material to support kiwifruit canopy,
but the wire often inhibits the normal growth of fruits, branches or trunks (Danbara, 1988). As shown in Fig. 1 (EG), fruits imbued with wire rust and fruits scratched or girdled by the wire were frequently observed. Abnormal growth of branches or trunks of kiwifruit may also result from girdling by the fence wire (Fig. 1H); some of the girdled branches failed to grow up. In this survey, the syndromes caused by fence wire were observed in all the examined orchards, but the disease incidence was less than $5 \%$ in each orchard (Table 2).

Excessive soil moisture can result in more serious and quicker damage or death to plants than lack of moisture. As a result of excessive soil moisture caused by poor drainage, the fibrous roots of plants decay because of the reduced supply of oxygen to the roots (Agrios, 2005). Inadequate or excessive watering may also cause similar symptoms. In this survey, wilting, root rots or disorganized roots were found on the kiwifruit trees in two orchards (Fig. 1I). Twenty-five out of 213 kiwifruit trees examined showed wilting in a poorly drained orchard in Beolgyo-eup, Boseong-gun, Jeonnam (Table 2). One out of 320 kiwifruit trees examined was killed by water stress at the orchard in Namwon-eup, Seogwipo-si, Jeju. Similar root rot and wilting symptoms on kiwifruit trees were previously reported, which were caused by Phytophthora drecsleri (Lee et al., 2001) and root-knot nematodes (Choo, 1985), respectively. Neither phytopathogenic fungi including $P$. 

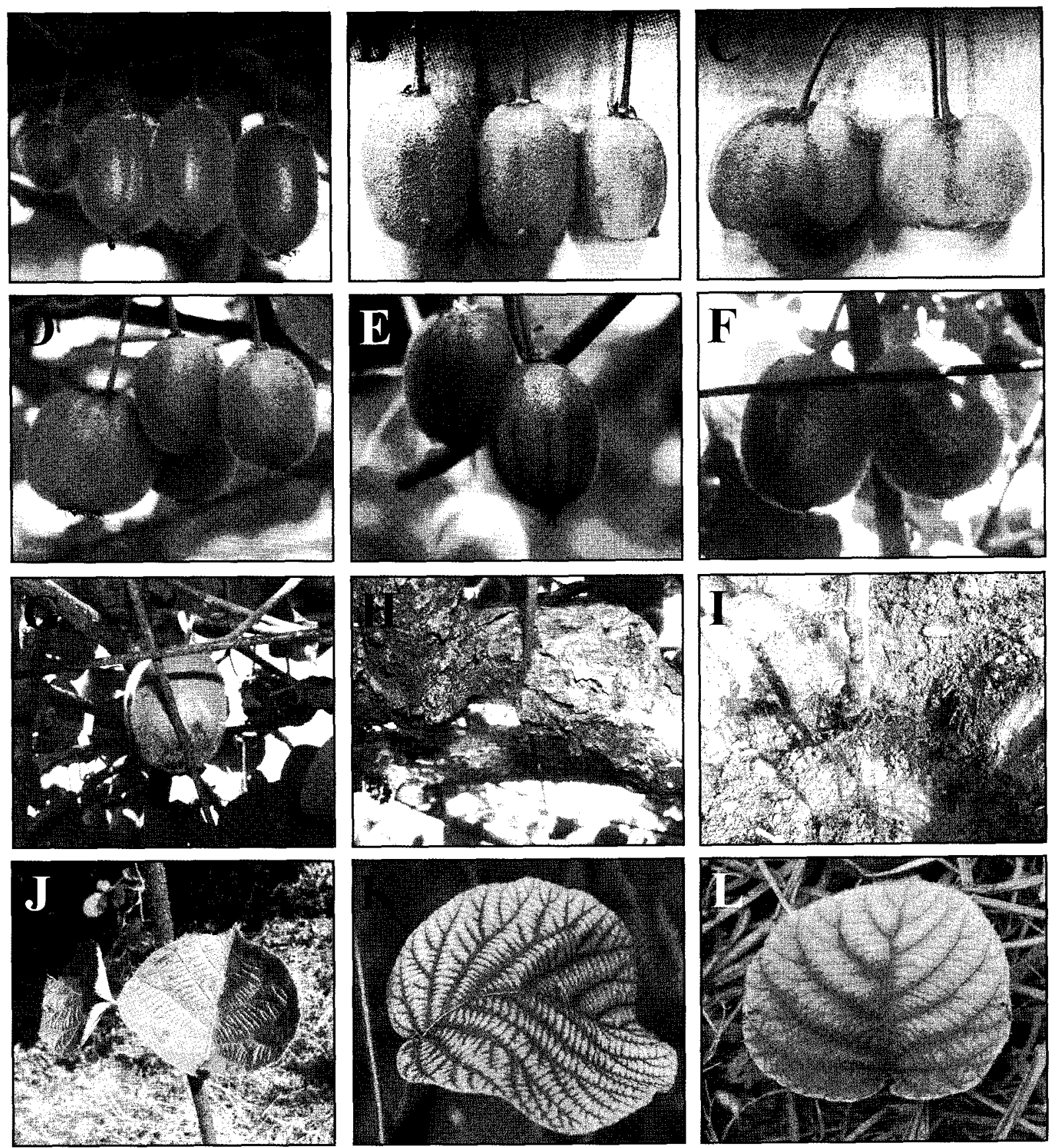

Fig. 1. Various kinds of abiotic diseases on kiwifruit trees caused by improper agricultural practices. (A-D) Malformed fruits caused by incomplete artificial pollination; A) Small fruit (left), B) Malformed fruits with a stripe and small process, C) Twin fruits, D) Wide fruit (left). (E-H) Injuries caused by fence wire; E) Imbued fruits with wire rust, F) Scratched fruits by wire, G) Girdled fruit by wire, H) Girdled branch by wire. (I) Root rots caused by poor draining. (J) Injury on a leaf from drift of herbicide. (K-L) Nutricnt deficiency symptoms; K) Manganese deficiency; L) Iron deficiency.

drecsleri nor the root-knot nematode was detected from the root or stem samples of the diseased trees in this study. Water stress caused by poor draining can be controlled by drainage using a culvert.

One of the most frequent injuries is caused by extensive use of herbicides (Eagle et al., 1981). Constantly increasing number of herbicides in use is creating numerous problems (Agrios, 2005). Necrotic spots were found on the lower leaves of kiwifruit trees cultivated at an orchard close to rice paddy fields in Seo-myeon, Suncheon-si, Jeonnam (Fig. 1J). The injury was turned out to occur by drift of the herbicide bentazone EC that was applied to kill weeds in 
the paddy fields right next to the kiwifruit orchard.

Kiwifruits require several mineral elements for normal growth (Bollard and Buter, 1966). When they are present in the tree in amounts smaller than the minimum levels required for normal growth, the tree becomes weak and exhibits various external and internal symptoms (Bennett, 1993). Manganese-deficient leaves became chlorotic but their smallest veins remained green and produced a checked effect. Iron-deficient leaves became severely chlorotic but their main veins remained green (Bang et al., 2006; Bennett, 1993; Korcak, 1987; Smith et al., 1987). Manganese-defrcient (Fig. 1K) and iron-deficient symptoms (Fig. 1L) were found on the leaves of kiwifruit trees in 5 and 2 orchards, respectively. Both symptoms were very similar to those determined by Bang et al. (2006). One or two trees were diseaséd in each orchard, but the incidence of manganese-deficient trees reached up to $43.8 \%$ (among 111 kiwifruit trees) in an orchard located in Doyang-eup,
Goheung-gun, Jeonnam (Table 2).

Abiotic diseases caused by unfavorable weather conditions. The minimum and maximum temperatures for plant normal growth vary greatly with plant species and growth stage. Tropical or subtropical plants such as kiwifruit grow best at a relatively high temperature and are injured severely when the temperature drops to near or below freezing. Such injuries on kiwifruits are usually caused by late frost in spring and freeze in winter. Sudden leaf blight on young shoots by late frost damage (Fig. 2A) and bark split on trunks by freeze damage (Fig. 2B) were quite often observed in open-field orchards. Late frost damage was found on the shoots of kiwifruit trees cultivated at 22 openfield orchards and freeze damage was also found on the trunks of kiwifruit trees at 7 open-field orchards in several locations of Jeonnam Province. Incidence of injured trees varied with the orchards, but reached up to $84.8 \%$ (among
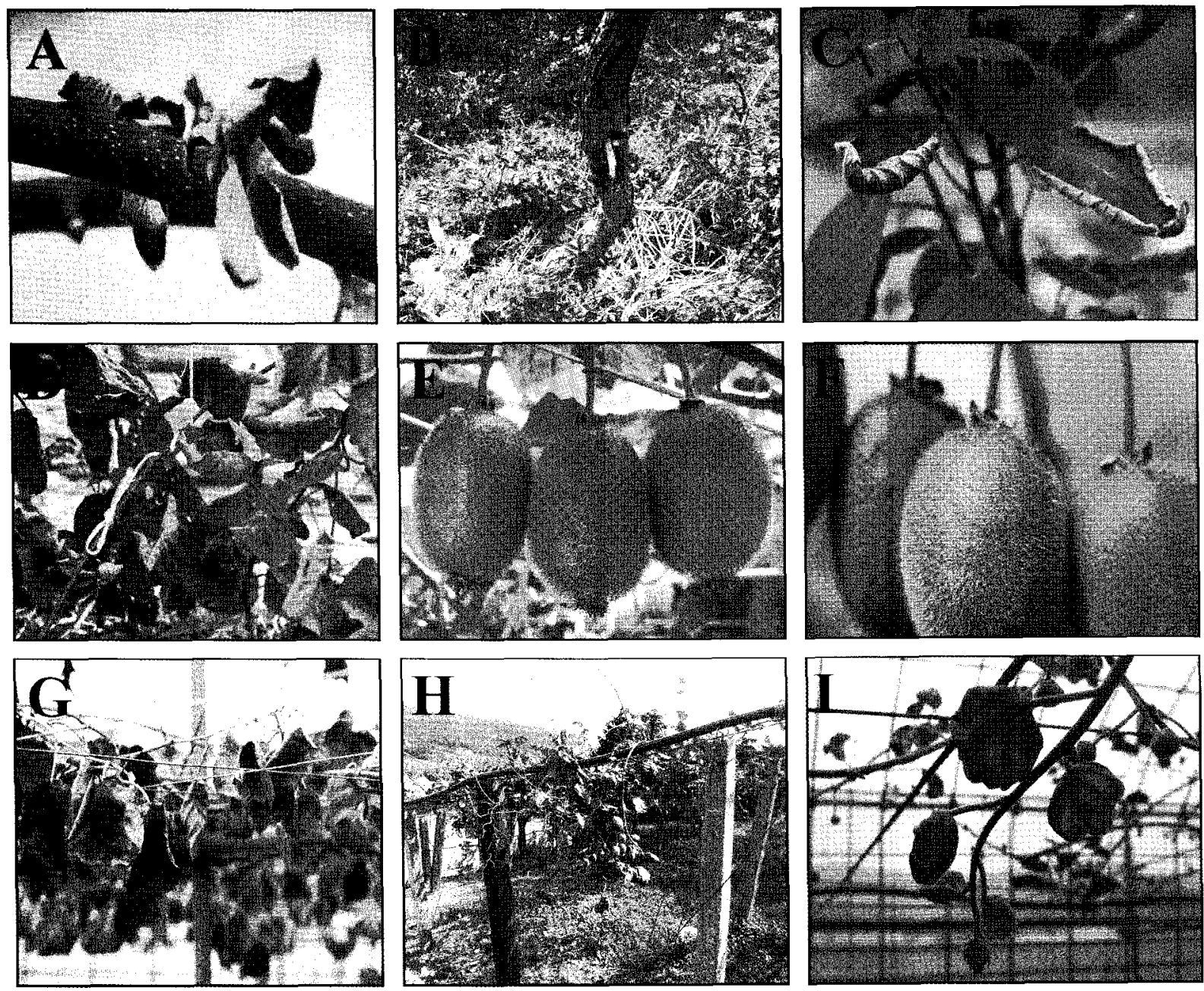

Fig. 2. Various kinds of abiotic diseases on kiwifruit trees caused by unfavorable weather conditions. (A-B) Low tempcrature injury; A) Leaf blight due to late frost, B) Bark split on trunks due to freezc. (C-D) High temperature injury; C) Leaf scorch due to insufficient water reaching the leaves, D) Leaf blight due to excessively high temperature and low relative humidity. (E) Healthy fruits. (F) Sunscald injury due to excessive light. (G-H) Typhoon damage; G) Flood damage, H) Wind damage. (I) Unknown syndrome; Cup-shaped leaves. 
Table 2. Incidences of abiotic diseases on kiwifruit trees grown at 62 orchards in 21 locations of Jeonnam and Jeju Provinces, Korea in 2007

\begin{tabular}{llcc}
\hline \hline Abiotic agents & Syndromes & $\begin{array}{c}\text { No. of orchards } \\
\text { diseased }\end{array}$ & $\begin{array}{c}\% \text { diseased } \\
\text { trees }\end{array}$ \\
\hline Incomplete pollination & $\begin{array}{l}\text { Malformed fruits such as small fruits, wide fruits, twin } \\
\text { fruits, etc. }\end{array}$ & 62 & $<1.0$ \\
Fence wire & $\begin{array}{l}\text { Fruits imbued with wire rust, fruits scratched or girdled by } \\
\text { the wire, branches girdled by the wire }\end{array}$ & 62 & $<5.0$ \\
Excessive soil moisture & Wilting, root rots, disorganized roots & 2 & $0.3-11.7$ \\
Herbicide & Necrotic spots on leaves & 1 & 10.0 \\
Manganese deficiency & Chlorosis of leaves & 5 & $1.0-43.8$ \\
Iron deficiency & Chlorosis of leaves & 2 & $<1.0$ \\
Late frost & Leaf blight & 22 & $>1.0^{*}$ \\
Freeze & Bark split & 7 & $10.0-84.8$ \\
High temperature & Leaf scorch, leaf blight & 2 & 100 \\
Excessive light & Sunscald of fruits & 62 & $<2.0$ \\
Flooding & Wilted trees & 1 & 88.9 \\
Strong wind & Defoliated, broken twigs or branches & 1 & 100 \\
\hline
\end{tabular}

${ }^{*}$ Severe leaf blight caused by late frost occurred in 22 kiwifruit orchards but the incidences were not exactly evaluated.

99 kiwifruit trees) in a severely injured orchard in Duweonmyeon, Goheung-gun, Jeonnam (Table 2). Low temperatures injure kiwifruits primarily by inducing ice formation between or within the cells. Ice formation in supercooled water within plants is greatly influenced by the epiphytic bacteria that act as catalysts for ice nucleation (Agrios, 2005). Frost and freezing seem to predispose the kiwifruit trees to bacterial canker since it has severely occurred on the trees after late frost or freeze (Koh et al., 1996; 2003). It is assumed that bacterial canker pathogen, Pseudomonas syringae pv. acitinidiae, might play an important role in ice formation in kiwifruit trees vulnerable to frost or freeze damages. This may be one of the plausible reasons for complete destruction of many orchards in several locations of Goheung-gun, Jeonnam. Plants are generally injured faster and to a greater extent when temperatures become higher than the maximum for growth than when they are lower than the minimum. The effect of high temperature on plants seems to be more dramatic when associated with other environmental factors, particularly excessive light, drought or low relative humidity (Agrios, 2005; Katterman, 1990). Leaf scorch (Fig. 2C) and blight (Fig. 2D) were observed on all of the kiwifruit trees cultivated at rain-proof orchards in Doyang-eup and Dodeok-myeon, Goheunggun, Jeonnam, respectively. Irregular areas on the leaves become pale green at first but soon collapse and form brown. Meteorological data and cultivation conditions supported the possibility that the injuries might be caused by excessively high temperature and low relative humidity when hot sunny days followed periods of cloudy, rainy weather. Leaf spots or blights of kiwifruits caused by several fungi are commonly found in the orchards during the growing season in Korea (Park et al., 2006). Bacterial leaf spot was also found in severely infected leaves of kiwifruits, which would be wilted and defoliated in Korea (Kim et al., 2006). However, any of the suspected causal organisms was not isolated from the scorched and blighted leaves of kiwifruits surveyed in this study.

Sunscald injuries (Fig. 2F) were also observed on the sun-exposed sides of fleshy fruits in all of the kiwifruit orchards surveyed, but the incidence of diseased fruits was less than $2 \%$ in each orchard (Table 2). High temperature of the fruit tissues beneath the surface facing the sun results in discoloration and a water-soaked appearance in hot, sunny days. Such similar symptoms are often found on the overripe fruits infected by ripe rot (Koh et al., 2005; Lee et al., 2001). Ripe rot caused by Botryosphaeria dothidea is seldom found on the fruits in the orchards, and watersoaked flesh tissue can be seen on the sunken part when the skin of the collapsed portion on the overripe fruits is peeled back after harvest. Such a pathogen was not detected from the fruits injured by sunscald in this survey.

Flooding results in wilting and death of plants by waterlogging during the growth season. A combination of high soil moisture and high soil or air temperature causes root collapse in waterlogged soils. High soil moisture reduces the amount of oxygen available to the roots, whereas high soil or air temperature increases the oxygen amount for plants. The two effects together result in an extreme lack of oxygen in the roots and cause their collapse and death (Agrios, 2005). Typical flood damage (Fig. 2G) occurred by typhoon 'Nari' on September, 2007. Approximately $90 \%$ of the 190 kiwifruit trees examined were wilted and killed by waterlogging at a severely damaged orchard 
located in paddy fields in Doyang-eup, Goheung-gun, Jeonnam (Table 2). Strong wind damage (Fig. $2 \mathrm{H}$ ) by the typhoon 'Nari' was also observed on the kiwifruit trees located at the regions close to the path of the typhoon. Most of the leaves on all examined kiwifruit trees defoliated and some of their twigs or branches were completely broken by the typhoon at an open-field orchard in Donggang-myeon, Goheung-gun, Jeonnam. Broken young shoots by strong wind were easily seen in open-field orchards during the growing season. Spring winds can break the tender young shoots at their point of attachment to the arm. Installation of rain-proof or wind-break shelters can alleviate the wind damage by strong wind or typhoon.

Unknown syndromes. Cup-shaped leaves (Fig. 2I) frequently occurred on young shoots in early spring and the incidence of this syndrome tends to increase annually in recent years. Bang et al. (2006) reported that the syndrome occurred frequently in paddy soil condition. When young seedlings were treated with low temperature under $-15^{\circ} \mathrm{C}$, the syndrome incidence was higher compared with untreated controls. However, the syndrome is not etiologically defined until now, and it is unknown why the syndrome occurs only on young expanding leaves in early spring both in open-field and rain-proof orchards. In this survey, the syndrome was easily observed in all of the orchards surveyed. The incidences of diseased trees and leaves reached up to $50 \%$ and $10 \%$ in severely damaged orchards, respectively.

\section{Acknowledgment}

This study was supported by Rural Development Administration, Ministry of Agriculture and Forestry, Republic of Korea.

\section{References}

Agrios, G. N. 2005. Plant Pathology. 5th ed. Elsevier Academic Press, Burlington, USA.

Bang, K. P., Lim, D. G. and Kim, B. H. 2006. Studies on Nutrition Diagnosis and Physiological Disorder of Kiwifruit. Rural Development Administration, Suwon, Korea.

Bennett, W. E. 1993. Nutrient Deficiencies and Toxicities in Crop Plants. APS Press, St. Paul, USA.

Bollard, E. G. and Buter, G. W. 1966. Mineral nutrition of plants. Ann. Rev. Plant Physiol. 17:77-112.

Choo, H. Y. 1985. A note on root-knot nematodes from Chinese gooseberry. Korean J. Plant Prot. 17:115.

Danbara, K. 1988. Kiwifruit Dictionary. Ehime Prefecture Fruit Agricultural Cooperative Association. Ehime, Japan.
Eagle, D. J., Caverly, D. J. and Holly, K. 1981. Diagnosis of Herbicide Damage to Crops. Chem. Publ., New York, USA.

Katterman, O. 1990. Environmental Injury to Plants. Academic Press, San Diego, USA.

Kim, G. H., Park, H. J., Lee, Y. S., Jung, J.-S. and Koh, Y. J. 2006. Outbreak of a new bacterial leaf spot disease on kiwifruit (Actinidia delisiosa) in Korea. Plant Pathol. J. 22:391.

Koh, Y. J. 1995. Economically important diseases of kiwifruit. Plant Dis. Agric. 1:3-13.

Koh, Y. J., Hur, J. S. and Jung, J. S. 2005. Postharvest fruit rots of kiwifruit (Actinidia delisiosa) in Korea. New Zealand J. Crop Hort. Sci. 33:303-310.

Koh, Y. J., Jung, J.-S. and Hur, J.-S. 2003. Current status of occurrence of major diseases on kiwifruits and their control in Korea. Acta Hort. 610:437-443.

Koh, Y. J., Lee, D. H., Shin, J. S. and Hur, J.-S. 2001. Chemical and cultural control of bacterial blossom blight of kiwifruit caused by Pseudomonas syringae in Korea. New Zealand $J$. Crop Hort. Sci. 29:29-34.

Koh, Y. J., Park, S. Y. and Lee, D. H. 1996. Characteristics of bacterial canker of kiwifruit occurring in Korea and its control by trunk injection. Korean J. Plant Pathol. 12:324-330.

Koh, Y. J., Seo, J. K., Lee, D. H., Shin, J. S. and Kim, S. H. 1999. Chemical control of bacterial canker of kiwifruit. Plant Dis. Agric. 5:95-99.

Korcak, R. F. 1987. Iron deficiency chlorosis. Hort. Rev. 9:133186.

The Korean Society of Plant Pathology. 2004. List of Plant Diseases in Korea. 4th ed. The Korean Society of Plant Pathol ogy. Seoul, Korea.

Lee, J. G., Lee, D. H., Park, S. Y., Hur, J.-S. and Koh, Y. J. 2001. Fist report of Diaporthe actinidiae, the causal organism of stem-end rot of kiwifruit in Korea. Plant Pathol. J. 17:110113.

Lee, J. H., Kim, J. H., Kim, G. H., Jung, J.-S., Hur, J.-S. and Koh, Y. J. 2005. Comparative analysis of Korean and Japanese strains of Pseudomonas syringae pv. actinidiae causing bacterial canker of kiwifruit. Plant Pathol. J. 21:119-126.

Lee, Y.-H., Jee, H-J., Cha, G. H., Ko, S. J. and Park, K. B. 2001. Phytophthora root rot of kiwifruit in Korea. Plant Pathol. J. 17:154-158.

Park, H. J., Jeong, I. H., Park, M. R., Lim, M. T., Lee, K. S., Park, J. H., Cho, S. J., Kim, G. H., Shin, S. H., Hur, J.-S., Jung, J.-S. and Koh, Y. J. 2006. Incidences and causal agents of leaf spots on kiwifruit (Actinidia deliciosa) grown in Korea. Plant Pathol. J. 22:423.

Smith, G. S., Asher, C. J. and Ckark, C. J. 1987. Kiwifruit Nutrition Diagnosis of Nutritional Disorders. Agpress Communications Ltd, Wellington North, New Zealand.

Warrington, I. J. and Weston, G. C. 1990. Kiwifruit: Science and Management. Ray Richards Publisher and New Zealand Society for Horticultural Science, Auckland, New Zealand. 